ENTREPRENEURSHIP AND SUSTAINABILITY ISSUES

ISSN 2345-0282 (online) http://jssidoi.org/jesi/

2019 Volume 7 Number 2 (December)

http://doi.org/10.9770/jesi.2019.7.2(25)

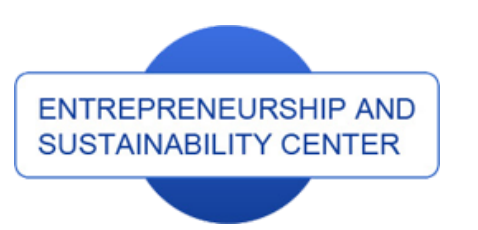

Publisher

http://jssidoi.org/esc/home

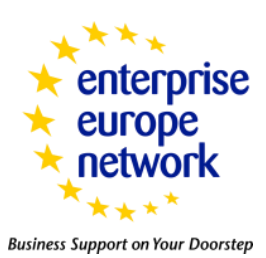

CASPA

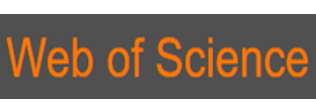

1) Clarivate

Analytics

\title{
AGRO-INDUSTRIAL CLUSTER: SUPPORTING THE FOOD SECURITY OF THE DEVELOPING MARKET ECONOMY
}

\section{Ravil Akhmadeev ${ }^{1}$, Alexander Redkin ${ }^{2}$, Nadezda Glubokova ${ }^{3}$, Olga Bykanova ${ }^{4}$, Liubov Malakhova ${ }^{5}$, Anatoly Rogov ${ }^{6}$}

\author{
1,3,4 Plekhanov Russian University of Economics (PRUE), Stremyanny Lane 36, 117997, Moscow, Russian Federation \\ ${ }^{2}$ Altai State University, Barnaul, Lenin Avenue, 61A, Barnaul, 656049, Russian Federation \\ ${ }^{5}$ Financial University of the Russian Federation Government of the Russian Federation, Leningradskiy prospekt, 49, 125993, \\ Moscow, Russian Federation \\ ${ }^{5}$ Public joint stock company «BANK URALSIB», Efremova Street, 8, 119048, Moscow, Russian Federation \\ ${ }^{6}$ Russian University of Transport, Obrazcova Street 9b9, 127994, Moscow, Russian Federation \\ E-mails: ${ }^{1}$ ahm_rav@mail.ru ; ${ }^{2}$ redkin.ag@yandex.ru ; ${ }^{3}$ glubokova@mail.ru ; \\ ${ }^{4}$ bykanova@inbox.ru ; ${ }^{5}$ ugli06@yandex.ru ; ${ }^{6}$ rogov_a@ rambler.ru
}

Received 12 March 2019; accepted 30 September 2019; published 15 December 2019

\begin{abstract}
The article examines the mechanism for the creation and implementation of an agro-industrial cluster in the form of a rural municipal formation, which is an average population center, whose inhabitants are engaged in agriculture and ensure the functioning of its social infrastructure. At the same time, the said cluster is a combination of a system of production, primary processing, storage and marketing of agricultural products and a system of social infrastructure that ensures the quality of life of its residents, comparable to the urban one. Within the framework of practical research, several measures for the integrated development of rural areas are proposed, taking into account the assessment of the level of social and economic development of agriculture in the territories of the constituent entities of the Russian Federation and public policy instruments that influence their development. The assessment of the agriculture development was carried out using the methods of descriptive statistics based on the Gatev coefficient, and also by conducting a cluster analysis based on the application of the package of applied programs "Statistica". These allowed to formulate and propose a concept for rural settlements of a new type that correspond to the current trends in the territorial development of the developing market economy that meet the requirements for ensuring the state's food security. At the same time, mechanisms proposed are aimed at the integrated development of rural settlements, and in particular, include the involvement of additional budgetary funds and adjusting the tax policy for agricultural producers.
\end{abstract}

Keywords: national food security; developing agricultural market; economy of agriculture; tax policy of agricultural producers

Reference to this paper should be made as follows: Akhmadeev, R., Redkin, A., Glubokova, N., Bykanova, O., Malakhova, L., Rogov, A. 2019. Agro-industrial cluster: supporting the food security of the developing market economy. Entrepreneurship and Sustainability Issues 7(2): 1149-1170. http://doi.org/10.9770/jesi.2019.7.2(25)

JEL Classifications: Q18, O50, R14 


\section{ENTREPRENEURSHIP AND SUSTAINABILITY ISSUES}

ISSN 2345-0282 (online) http://jssidoi.org/jesi/

2019 Volume 7 Number 2 (December)

http://doi.org/10.9770/jesi.2019.7.2(25)

\section{Introduction}

One third of the developing country economy branches is related with the agro-industrial complex. According to expert estimates, the creation of one workplace in the agricultural sector allows employment of 5-6 people in other spheres of the economy, and the growth of agricultural production by $1 \%$ ensures the growth of the entire economy by 2.0-2.3\% (Bonanno, et al. 2019). At the same time, the agriculture occupies a special position in market conditions, which does not allow full participation in inter-industry competition. The reason is that agricultural sector is falling behind in comparison with the rest sectors due to the dependence on natural factors and the seasonal (cyclical) nature of production. The return on invested capital in this area is less than in industry, but the level of agricultural production directly affects the state of the country's food security. At the same time, the agricultural sector is less adaptive than other sectors; nevertheless, its condition also depends on changes in the economic situation and technological platforms (Tarman and Acun, 2010; Shatunova et al., 2019; Goryushkina et al., 2018). Due to a complex geopolitical situation, the problem of replacing imported products with food products produced domestically (the policy of import substitution) has arisen in the current Russian economy. To successfully solve this problem, it is necessary to institutionalize import substitution, which is understood as the creation of an institutional environment that allows replacing imports of agricultural goods (works, services) with competitive domestic products that are not inferior to foreign analogues in terms of their price and consumer properties.

\section{Literature review}

It should be noted that almost every country has a large number of various instruments regulating the economic activities that are designed to implement protectionist policies in order to replace imported agricultural products (goods, works and services) with national (domestic) ones. Among such instruments are budget subsidies, tax benefits, price, credit and other preferences (Strasberg et al., 1999; Sharafutdinov et al., 2018; Trofimova et al., 2019; Baltgailis 2019). Taking into account that each of the abovementioned tools has advantages and disadvantages, it should be emphasized that their effectiveness depends on the institutional environment in which it operates (Tagliafierro et al., 2013; Rupeika-Apoga et al., 2018; Kuznetsova et al., 2019; Bozhkova et al., 2019; Titova et al., 2019; Sycheva et al., 2019).

At the same time, the institutionalization of import substitution should be carried out in the context of industries that are essential for ensuring the economic and food security of the state - primarily in industry and agriculture (Xiaojiao et al., 2018). Moreover, when applying a specific instrument of state support for import substitution, it is necessary to take into account the systematic nature of the import substitution process that is, taking into account the mutual influence of the measures of state financial support on the incentive subject. For example, tax methods of regulating the activities of economic entities contribute to the development of those market participants who receive tax incentives (Bodyako et al., 2019). At the same time, their wide application causes the emergence of "falling" tax revenues, thus limiting the possibility to apply budget subsidies.

In turn, price methods for regulating import substitution appear to be discriminatory in comparison with tax methods that are universal in nature. The use of price regulators can lead to restriction or elimination of competition, and does not stimulate the improvement of the quality of national products, so the application of these methods should be short-termed and accurate (Hoekman et al., 2004). Considering that the negative effect of direct import substitution is the country's withdrawal from the globalization process (the sanctions policy), the state will not be able to take advantage of the global distribution of material, labor and other resources to the proper extent (Makki et al., 2012; Dunets et al., 2019). In this regard, the financial support of the state for the production of competitive agricultural products is of particular importance. 


\section{ENTREPRENEURSHIP AND SUSTAINABILITY ISSUES}

ISSN 2345-0282 (online) http://jssidoi.org/jesi/

2019 Volume 7 Number 2 (December)

http://doi.org/10.9770/jesi.2019.7.2(25)

The credit mechanisms for import substitution stimulating relate to another method of import substitution regulation. Over the past three years, the Russian Ministry of Agriculture has approved 464 investment projects for import substitution, for which over 4.2 billion US dollars will be allocated for the period up to 2020 (Ministry of Economic Development Order of 25.03. 2014 No. 155 "On the conditions for admission of goods originating from foreign countries for the purpose of procuring goods, works, and services for the provision of state and municipal needs"). About 4.1 billion US dollars will be invested in the development of vegetable growing of protected soil. The investments will also be made in the sphere of sheltered soil vegetable growing, construction of vegetable stores, processing of fruits and berries, dairy cattle. However, the credit mechanisms have practically "exhausted" their resources in conditions of high creditworthiness of agricultural commodity producers and the underdevelopment of agricultural credit cooperatives (Jeffrey et al., 2018). At the same time, credit cooperatives are very important in the world practice (e.g. in the US, the cooperative farm loan system provides farmers with at least $1 / 3$ of the loans for land purchase and 1/6 of the volume of short- and medium-term loans (Asmi et al., 2018).

\section{Theoretical background}

In connection with the chronic unprofitability of a significant part of economic entities in the agricultural sector of developing countries, it appears necessary to assess the potential for reducing this indicator by minimizing the expenditure part of their budgets. This can be achieved by analyzing the structure of the cost of agricultural products. The cost price should be the total amount of current costs of commodity producers for the production and sale of products. The production cost, including all current costs for the technological process and management should be distinguished as well as the full (commercial) cost price, taking into account the costs of selling products (Jones, 2019; Goryushkina et al., 2019; Singareddy et al., 2019; Goloshchapova et al., 2018; Tarman, and Dev, 2018).

At the same time, the prime cost is the most important general performance indicator of the entrepreneurial activity, which determines the efficiency of their production and competitiveness in the internal and external markets. In comparison with sales prices, the total cost price determines the amount of profit or loss, as well as the level of profitability (Korableva et al., 2018). The cost price, according to Semeta A. (2011) is systematically determined in agricultural organizations in the process of accounting and is subject to analysis and management.

The production of agricultural products is the most risky kind of entrepreneurial activity, because along with various types of economic risks (Skryl, 2017), this sector is also characterized by risks caused by adverse natural and climatic factors. The ranking of risks based on expert assessments carried out by Guerrero, J.W.G. at all (2018), states that among the most significant risks are natural and climatic risks. The probability of occurrence of these risks and, consequently, their negative impact on the result of entrepreneurial activity in the agroindustrial complex amounts to 0.792. According to Palleto, A. et all (2015), seasonal alignment significantly affects economic efficiency in world agricultural practices, and is unevenly distributed per unit area of agricultural land. This is confirmed by statistical studies carried out using OECD statistic (Balanced International Merchandise Trade Statistics data for 20 non-OECD countries) (Figure 1). 


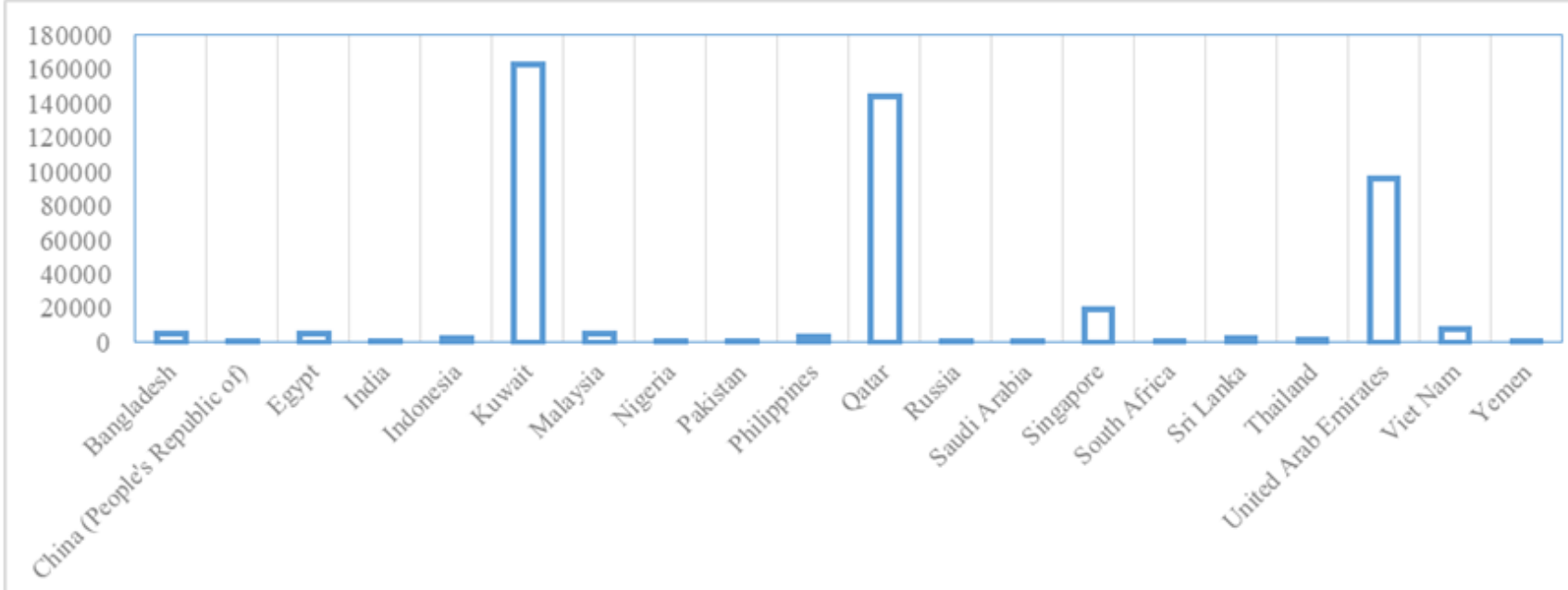

Fig. 1. The ratio of agricultural output per conditional unit of land occupied by agriculture in countries that are not members of the OECD in 2011, (shares)

Source: Balanced International Merchandise Trade Statistics (by CPA)

According to Fig. 1, the Russian Federation in terms of the ratio of agricultural output to the area of land occupied by agriculture is among the countries that are not members of the OECD with the lowest indicator. Moreover, according to the study of the dynamics of the change in the specific volume of agricultural products to the conventional unit of the area for non-OECD countries, for the period 2011-2016, Russian Federation has the smallest indicators (Figure 2).

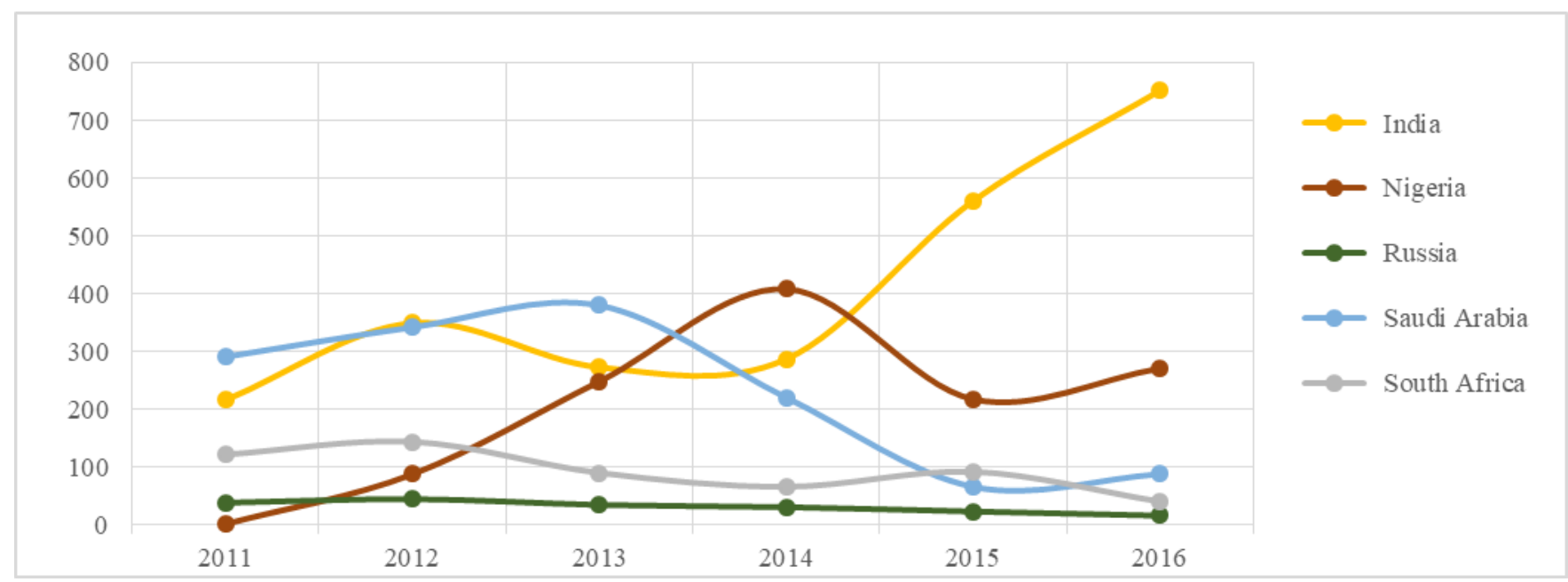

Fig. 2. Dynamics of the change in the specific volume of agricultural products to the conventional unit area for individual countries that are not members of the OECD

Source: Balanced International Merchandise Trade Statistics (by CPA)

In this case, it is possible to identify several obvious risks immanent to developing economies, and inherent exclusively in the Russian agricultural sector: 


\section{ENTREPRENEURSHIP AND SUSTAINABILITY ISSUES}

ISSN 2345-0282 (online) http://jssidoi.org/jesi/

2019 Volume 7 Number 2 (December)

http://doi.org/10.9770/jesi.2019.7.2(25)

a)the risk of reducing the competitiveness of domestic agricultural products, producers of which are not able to compete on an equal footing with international agricultural producers (Hayami and Ruttan, 1970);

b)the risk of the inability to purchase innovative agricultural equipment, in order to increase production volumes;

c)risk of incorrect and untimely adaptation of Russian agricultural production to changing market conditions, a disproportionate reduction in the supply of agricultural products in accordance with the demand for it (Ivanova, et. al, 2018). At the same time, this risk can be realized in the following way: due to the natural limitedness of sown areas, Russian producers will not be able to timely increase the output of crop production in response to the increasing demand;

d)the risk of low added value of agricultural products, caused by the disparity of prices between the values of production and resources (feed, agricultural machinery, fertilizers, etc.) required for its production (Siskova J., 2015);

e)the risk of inability to attract investors to agricultural production projects due to their limited attractiveness.

When different types of risks were identified for agricultural producers after the introduction of the food embargo over the past four years, the following main problems characteristic of the Russian agricultural market were formulated. Increase in the risk of bankruptcy of agricultural producers. If an entrepreneur is faced with the inability to pay interest or the bulk of the amount of debt, then later credit institutions are less likely to agree to a concessional loan, which would serve as a basis for increasing the financial and operational sustainability of the entrepreneur. At the same time, preferential loans provided by credit organizations and agricultural credit consumer cooperatives to producers in accordance with the current state programs for the development of agriculture and the regulation of markets for agricultural products, raw materials and food for the period until 2020 can not be repaid in time for various reasons. Firstly, the agricultural products have low added value, which significantly reduces the profitability of sales, and because of this, the agricultural organization or the peasant and individual farm holdings accumulate free cash to repay loans extremely slow. Secondly, agricultural commodity producers face difficulties in the marketing of crop and livestock products, as the threshold of entry is extremely high in retail chains. Impossibility to sell the products directly causes the risk of inability to repay the loan. Thirdly, the risks arising in the conditions of the food embargo are one of the reasons for changing the legal acts related to the agricultural producers' activities in Russia.

It should be noted that the risk of agricultural producers, caused by introduction of the food embargo, is associated with a longtime process of collecting the documents required to receive subsidies and benefits for conducting business in agriculture (Voronkova et al., 2019; Prodanova et al., 2019). In particular, the Ministry of Agriculture of the Russian Federation establishes an extensive list of documents for subsidizing the percentage load in accordance with the State Program for the Development of Agriculture and the Regulation of Agricultural, Raw Materials and Food Markets for the Period up to 2020. These documents include: contracts for the sale of products plant growing and livestock, primary documents, bank documents, which confirm that agricultural producer owns the necessary sum (10\% of the amount of the requested grant), as well as business - plans for the sale of agricultural products. The complexity of the procedure of preparing these documents increases the risk of making mistakes and, as a result, the risk of refusal to grant a subsidy also increases. The risks mentioned above can lead to various negative consequences, the nature of which depends on the category of farms to which the agricultural producer belongs (Bloshenko, et. al, 2017; Plaskova et al., 2017). The main problems for agricultural organizations in developing countries thus are:

a)impossibility to attract agricultural workers;

b)impossibility to acquire high-tech agricultural machinery in the short term;

c)impossibility to ensure a reduction in the price of manufactured products in a short time.

In turn, the following problems in entrepreneurial activities can emerge for peasant and individual farm holdings and individual entrepreneurs:

d)impossibility to sell their products due to high competition with larger agricultural producers;

e)impossibility to acquire high-tech agricultural machinery in the short term; 


\section{ENTREPRENEURSHIP AND SUSTAINABILITY ISSUES}

ISSN 2345-0282 (online) http://jssidoi.org/jesi/

2019 Volume 7 Number 2 (December)

http://doi.org/10.9770/jesi.2019.7.2(25)

f)the need to raise the price of their products in order to cover costs in the midst of an economic crisis.

In this regard, the definition of indicators of dynamics, structure, structural shifts, trends in the development of agricultural production, modeling of agricultural production will allow to identify the features of the development of the Russian market of agricultural products and, consequently, to determine ways to minimize the risks previously considered.

\section{Data analysis}

The main indicator characterizing the results of entrepreneurial activity of agricultural producers in the sub-sector of crop production is the gross harvest of agricultural crops in farms of all categories. In order to identify the economic characteristics of crop production, it seems necessary to determine the distribution of gross revenues by type of agricultural producers. On the other hand, it is advisable to identify the factors responsible for changing the structure of gross receipts and the economic reasons for these changes (Figure 3).

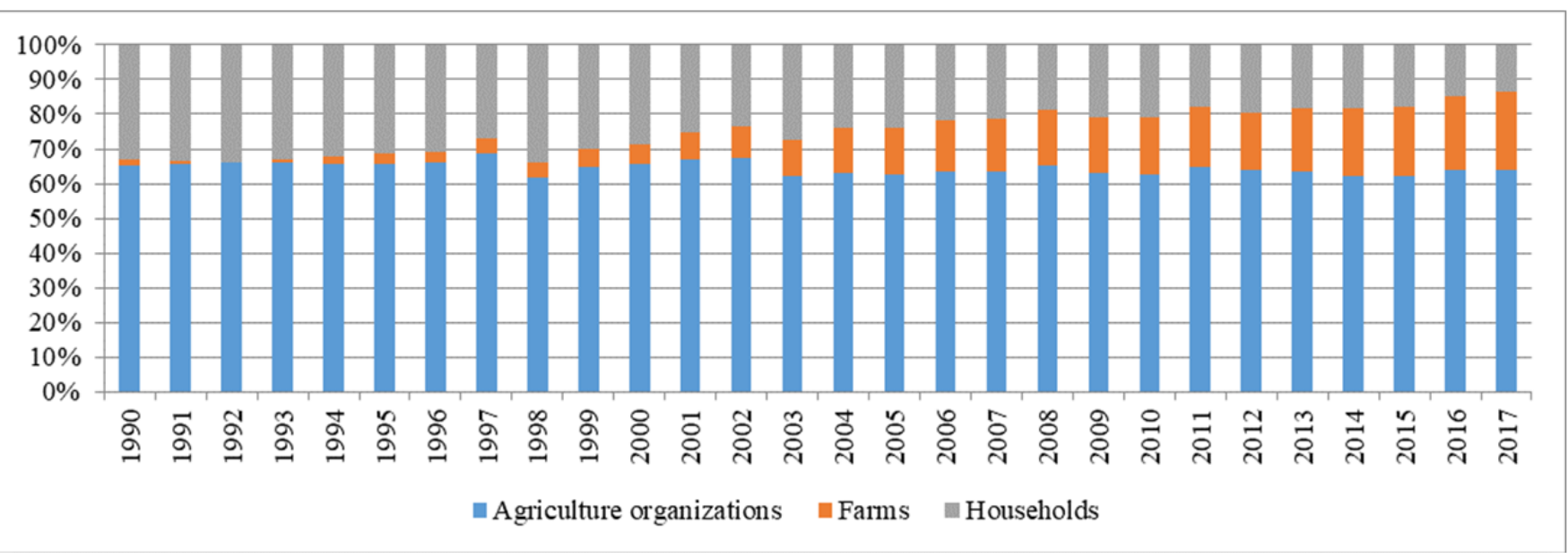

Fig. 3. Structure of gross harvest of agricultural crops by major producers in the Russian Federation in 1990-2017 (\%) Source: Federal State Statistics Service (Rosstat) https://www.gks.ru

Analysis of the structure of gross harvest of agricultural crops showed that in 1990-2017, the largest share belonged to organizations considered as agricultural producers in accordance with the Federal Law of 08.12.1995 N 193-FZ "On Agricultural Cooperation" (Figure 3). Thus, in 2016 and in 2017, 63.90\% and 64.05\% of the gross collection, respectively, fell on this category of agricultural producers - that is, the specific weight increased by $0.16 \%$. The specific weight of the gross harvest, attributable to peasant and individual farm holdings and individual entrepreneurs, amounted to $21.14 \%$ in 2016, and in 2017 - to $22.56 \%$, that is, the increase made up $1.41 \%$. In turn, the share of the gross collection, which falls on the economy of the population, in 2016 was $14.96 \%$, and in $2017-13.39 \%$ (the absolute growth of the structure was $-1.57 \%$ ).

However, for the period 2016-2017, the largest share in the structure of gross revenues fell on agricultural organizations. This is explained by the fact that this type of agricultural producers has the highest economic stability in comparison with others. Agricultural organizations easily overcome market barriers at the entrance to retail and wholesale trade networks, carry out significant advertising costs (the largest market players are represented by Miratorg Holding and Agro-Alliance Holding), and that ensures a consistently high demand for their products (Kevorkova et.al., 2019). As a result, agricultural organizations accumulate funds that allow 


\section{ENTREPRENEURSHIP AND SUSTAINABILITY ISSUES}

ISSN 2345-0282 (online) http://jssidoi.org/jesi/

2019 Volume 7 Number 2 (December)

http://doi.org/10.9770/jesi.2019.7.2(25)

increasing the gross collection due to intensive and extensive development paths. In turn, the decrease in the share of households in 2016-2017 can be explained by the loss of interest in personal farming households.

The activities of in comparison with others do not have such a scale as agricultural organizations. However, the share of this category of farms is increasing in 2016-2017. The reason for this is subsidizing by the state of interest rates on loans for peasant and individual farm holdings after the food embargo was established. The growth in the use of financial resources becomes the basis for increasing gross revenues. At the same time, the change in the structure of the gross collection in 2017 in comparison with 1990 is explained precisely by an increase in the share of peasant and individual farm holdings and individual entrepreneurs by $20.89 \%$ and a decrease in the share of households in the population by $20.25 \%$ (Figure 4 ).

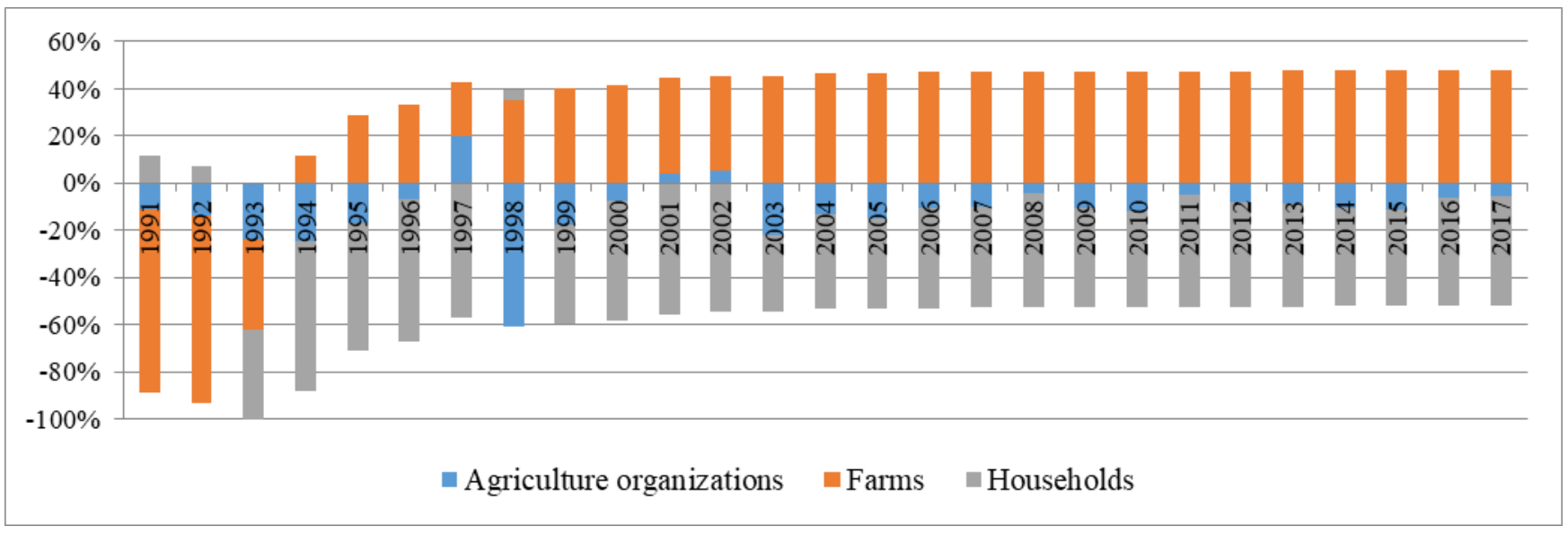

Fig. 4. Absolute changes in the structure of gross crop collection by categories of farms in the Russian Federation in 1991 - 2017 (in comparison with 1990, percentage points)

Source: Federal State Statistics Service (Rosstat) https://www.gks.ru

These changes in the structure of gross collection are determined by political and legal reasons. The entrepreneurial activity in the Russian Federation has increased in the 1990s: families owning large personal subsidiary plots were registered as individual entrepreneurs or created peasant and individual farm holdings, that is, they transferred the holding to organizational and legal forms, the purpose of which is to extract profit. In this regard, a comprehensive assessment of the differences in the structure of gross crop collection based on the application of the coefficient proposed by the Bulgarian professor. K. Gatev (Gatev and Galieva, 2008), should be carried out in accordance with the following formula:

$$
K_{G}=\sqrt{\frac{\sum_{i}\left(d_{1 i}-d_{0 i}\right)^{2}}{\sum_{i} d_{1 i}^{2}+\sum_{i i} d_{o i}^{2}}}
$$

where $\mathrm{d}_{1 \mathrm{i}}$ - specific weight of the $\mathrm{i}$-th agricultural producer in the reporting period;

$\mathrm{d}_{2 \mathrm{i}}$ - specific weight of the $\mathrm{i}$-th agricultural producer in the base period.

As is known, the change in the statistical indicators of the structure of any studied population (in particular, the gross collection of agricultural crops) is associated not only with the quantitative change of individual elements of the system, but also with changes in the structure of the population itself. In the theory and practice of statistical analysis, a special place belongs to the composite indicators of the estimation of structural shifts that have a convenient and compact scale of values - from 0 to 1 (the closer the value of the coefficient to 1 , the stronger the differences in the structure), and also are universal, normalized and sufficient sensitive to structural shifts. As such can be considered the integral coefficient of structural differences K. Gatev, the index of structural differences A. Salai and the rank correlation coefficient of Spearman (Petkov L., 2017). For the generalized assessment of structural changes in the gross harvest of agricultural crops, the Gatev coefficient is used in the 
study, since it is the easiest for calculation, while its interpretation is analogous to other coefficients of structural shifts (the Ryabtsev coefficients, Salai, etc.). In comparison with 1990, the structure of gross harvest by farm categories in 2017 has survived a slight change, since the Gatev coefficient was 0.11 (Appendix 1).

When studying the characteristics of agricultural production, it is essential to consider regional differences in the gross harvest of agricultural crops structure in order to identify the regions of the Russian Federation that are the main suppliers of crops. The largest share in 2017 was made by the Central Federal District (28.94\%), and the smallest - by the Far Eastern Federal District (2.30\%) (Figure 5).

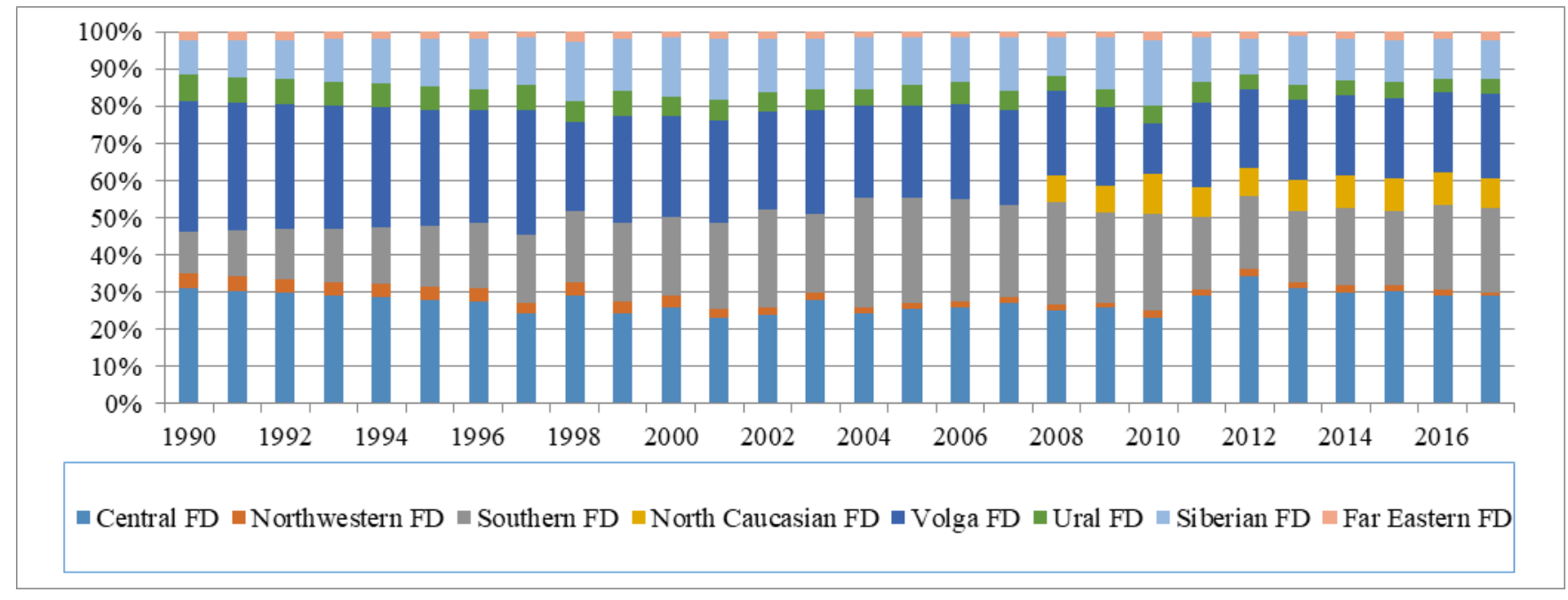

Fig. 5 Structure of gross crop collection in the Russian Federation by federal districts in 1990-2016 (\%)

Source: Federal State Statistics Service (Rosstat) https://www.gks.ru

The specified features of the gross harvest structure (Fig.5), are primarily determined by natural and climatic conditions suitable for cultivation of agricultural crops. The smallest specific weight of the Far Eastern Federal District is also determined by the same reason. Another reason is the higher level of the banking system development in the Central Federal District compared to other federal districts - so that agricultural commodity producers operating in the Central Federal District have higher opportunities to obtain preferential loans for the development of their enterprise (in particular, for the purchase of selection seeds and seedlings, fertilizers and agricultural machinery). At the same time, if in 1990 the largest share was in the Volga Federal District (35.23\%), and the smallest - also in the Far Eastern Federal District (2.19\%), then in 2017 the Volga Federal District the share decreased by $12.50 \%$. The reason of this change was decrease in the level of availability of financial and technological resources for agricultural producers in the Volga Federal District. Various factors determine the agricultural crop production. In our opinion, the size of sown areas (thousand hectares) is the most significant, since this indicator characterizes the supply of Russian agricultural producers with land resources (Figure 6). 


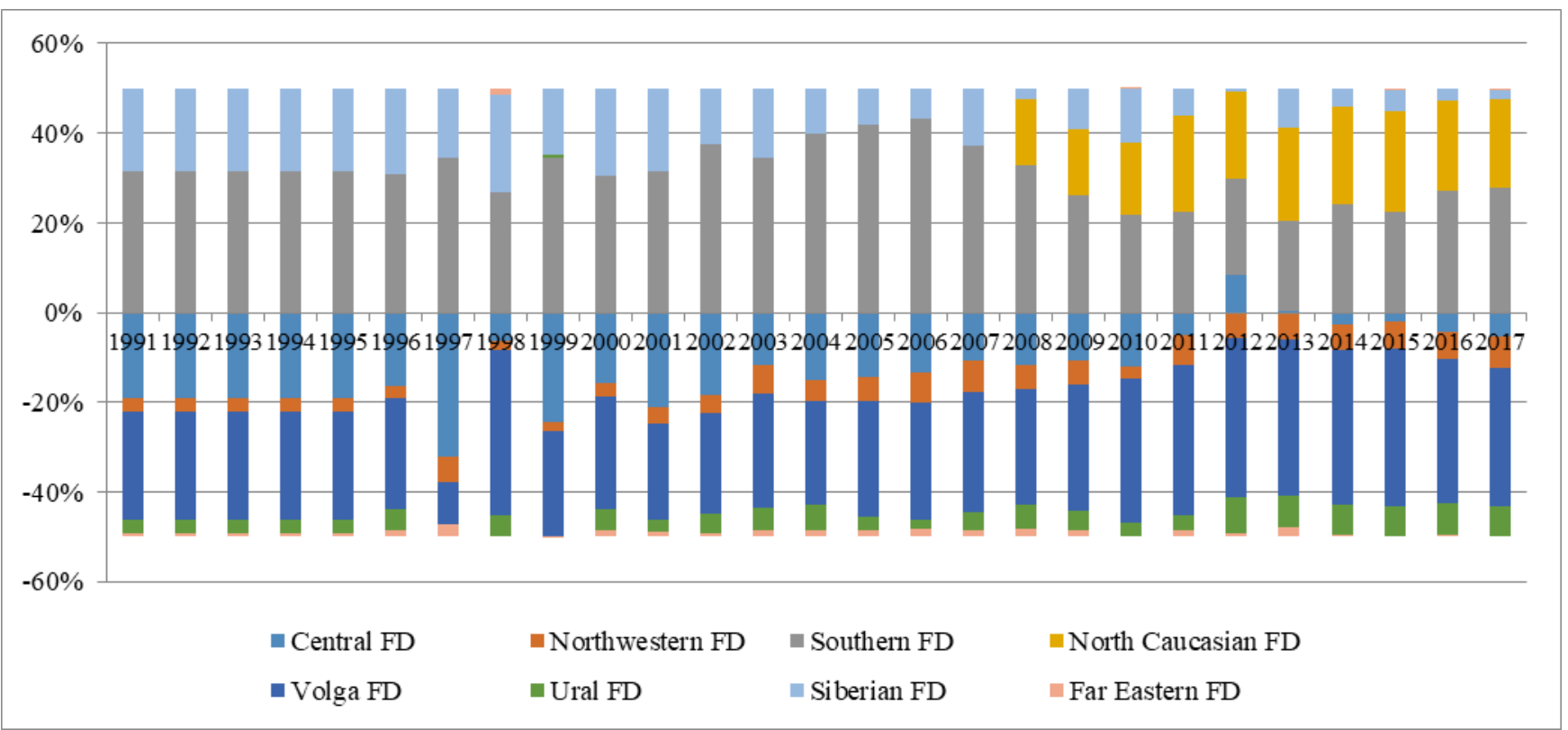

Fig. 6 Absolute changes in the structure of gross crop collection by federal districts of the Russian Federation in 1991 - 2017 (in comparison with $1990, \%)$

Source: Federal State Statistics Service (Rosstat) https://www.gks.ru

In 2017, the largest share in the structure of sown areas was made by the Volga Federal District (29.70\%), and the smallest - by the Northwest Federal District (1.78\%) (Appendix 1). In 1990, the Volga Federal District also made the largest share $(30.18 \%)$. This is due to the fact that chernozems and meadow-chernozem soils in this region are favorable for the cultivation of agricultural crops. That is why, compared to 1990, the change in the structure of cultivated areas has been insignificant - the Gatev coefficient was 0.09 (Appendix 2). When studying the Russian agriculture state, it is necessary to take into account not only the indicators of the crop production sub-sector, but also the indicators of animal husbandry: the volume of meat, milk and eggs production. These products are classified as strategic, due to their high nutritional value (Kiseleva, et. al, 2019). Therefore, it is necessary to determine which federal districts of the Russian Federation are the main suppliers of meat and meat products to the Russian market. The obtained results can be used in the formation and adjustment of state programs aimed at the development of meat production (Fig. 7). 


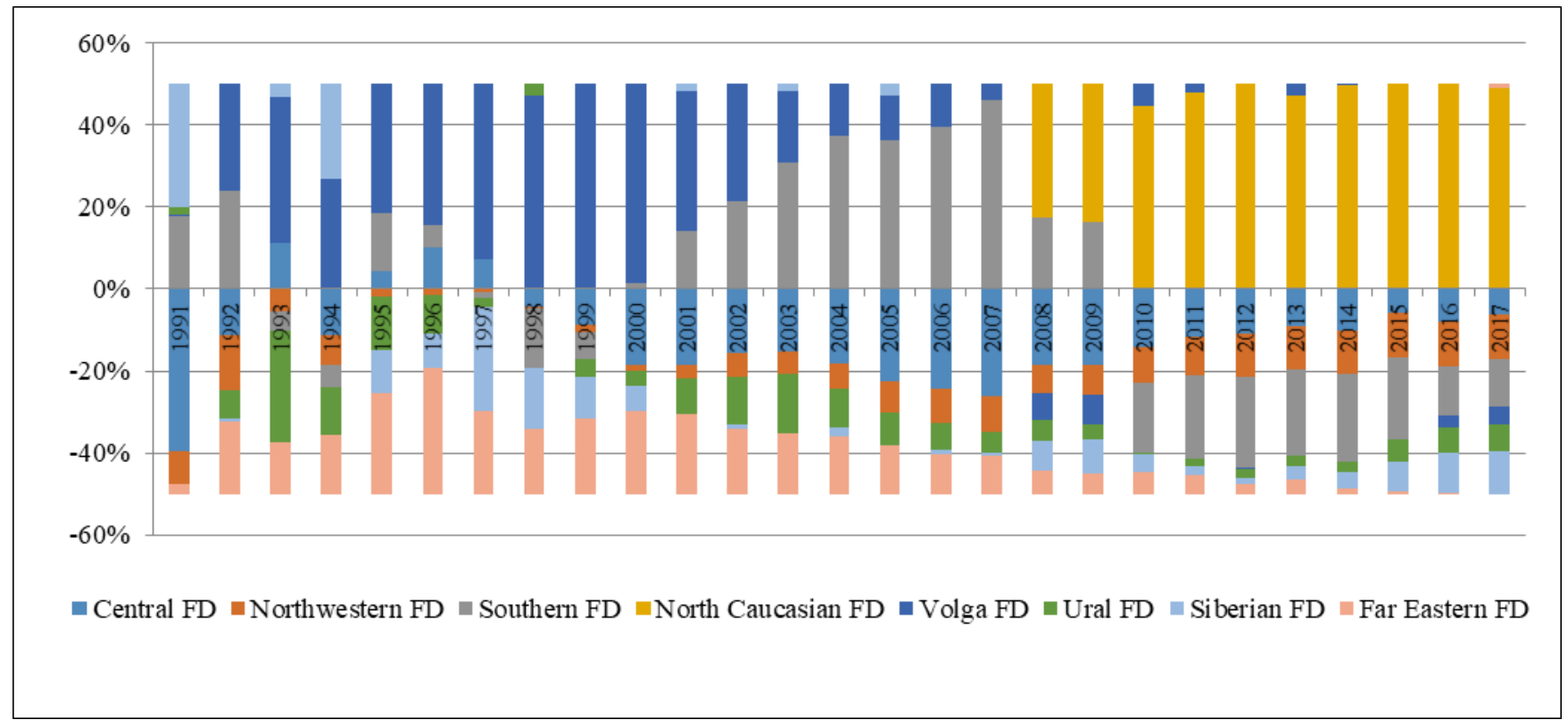

Fig. 7. Absolute changes in the structure of acreage of agricultural crops in the federal districts of the Russian Federation in 1991 - 2017 (in comparison with $1990, \%$ )

Source: Federal State Statistics Service (Rosstat) https://www.gks.ru

Basing on the analysis of regional differentiation of the main indicators of the state of Russian agriculture, the following main conclusions can be formulated:

a)the largest volume of crop production, as well as livestock and poultry for slaughter (in slaughter weight) falls on the Central Federal District;

b)the largest crops-cultivating areas, as well as the highest level of milk and eggs production, and the consumption of fodder for livestock and poultry are in the Volga Federal District;

c)far Eastern Federal District can be characterized by the lowest values of agricultural development indicators.

The analysis made it possible to identify and characterize the development of the Russian crop production and livestock production market, taking into account the regional component. In our opinion, further research of the problems of food security of the state will be advisable in the direction of studying the systematic risks that accompany the activities of economic entities in the agricultural sphere.

\section{Results}

The study proposes to use mechanisms for creating cluster projects in the agricultural sector as a method of complex impact on the factors of systematic risks (in particular, price and volume risks) that affect the country's economic security. At the same time, the creation of cluster projects is one of the key methods to reduce the systematic risks inherent in the activities of economic entities in the agricultural sector. The cluster projects formation is aimed at solving the main problems of the agricultural sector related to the processing, storage, sale of products, as well as personnel and social issues. It should be noted that the implementation of cluster projects is the most promising form of state activity (in relation with spending public funds or simply mobilizing the public and public resources). 


\section{ENTREPRENEURSHIP AND SUSTAINABILITY ISSUES}

ISSN 2345-0282 (online) http://jssidoi.org/jesi/

2019 Volume 7 Number 2 (December)

http://doi.org/10.9770/jesi.2019.7.2(25)

The designed form of implementing the state functions has a number of advantages:

a) clarity in setting goals facilitates the process of controlling the movement of cash flows;

b)concentration of financial resources allows to achieve results, avoiding the effect of "financial resources

dilution";

c)increase of the possibilities for evaluating the effectiveness of program implementation.

While studying the results of entrepreneurial activity of agricultural producers in the Russian Federation constituencies, it is necessary to determine classes of regions that are similar to each other. In this regard, the relevance of the application of cluster analysis is increasing. Thus, a set of indicators that determine the volume of production of crop production can be considered:

a)gross collection of agricultural crops (thousand centers);

b)sown areas (thousand hectares);

c)average annual number of employed in agriculture (thousand people).

The cluster analysis was conducted using the method of tree-like clustering - since the clusters of Russian Federation constituencies differ by the level of crop production development in 2017 (clusters of dissimilarity or distances between objects (the territories of the Russian Federation constituent entities)). In this case, the objects were combined into clusters based on the Ward method (Ward J.H., 1963), since it allows the formation of clusters with a minimal intraclass variation. At the same time, the proximity between regions was estimated on the basis of the Euclidean distance metric. It should be noted that the use of the Ward method as one of the methods of hierarchical cluster analysis involves the unification of those objects that give the least increment in the sum of squares of deviations from the mean values, $V_{k}=\sum_{i=1}^{n_{k}} \sum_{j=1}^{p}\left(x_{i j}-\overline{x_{j k}}\right)^{2}$ which leads to the formation of clusters of approximately the same size (Murray and Ginman, 1976). Note that each object can be described by $r$ signs, and hence it can be represented as a point of r-dimensional space and it can be estimated in comparison with objects by means of the distance between them on the basis of the Euclidean space metric:

$$
\rho_{i j}=\sqrt{\sum_{\mathrm{r}=1}^{\mathrm{m}}\left(\mathrm{x}_{\mathrm{ir}}-\mathrm{x}_{\mathrm{jr}}\right)^{2}}
$$

Figure 8 presents the results of a cluster project for the Russian Federation constituent entities, taking into account the factors affecting the production of crops. When building clusters, a software package "Statistica" (developed by StatSoft) was applied, and that allowed to carry out cluster analysis by a hierarchical method (Pulford G., 2005). In general, 3 classes of regions of the Russian Federation, can be distinguished (Fig. 8).

The first cluster includes the following regions: the Novgorod Region, the Arkhangelsk Region, the Republic of Sakha (Yakutia), the Khabarovsk Territory, the Karachay-Cherkess Republic, the Republic of North OssetiaAlania, Moscow, Murmansk Region, the Republic of Karelia, Kamchatka, Sakhalin Region, Sevastopol, the Chukotka Autonomous District, the Magadan Region, the Yamalo-Nenets Autonomous District, the Republic of Ingushetia, the Khanty-Mansi Autonomous Area - Yugra, the Republic of Tuva.

The second cluster includes: the Ryazan Region, the Republic of Mordovia, the Kurgan Region, the Kemerovo Region, the Amur Region, the Tver Region, the Zabaikalsky Region, the Astrakhan Region, the KabardinoBalkaria Republic, the Chechen Republic, the Republic of Crimea, the Moscow Region, the Leningrad Region, the Udmurt Republic, the Sverdlovsk Region, The Penza Region, the Tyumen Region, the Krasnoyarsk Territory, the Samara Region, the Chelyabinsk Region, the Novosibirsk Region, the Republic of Dagestan, the Kursk Region, the Tambov Region. 


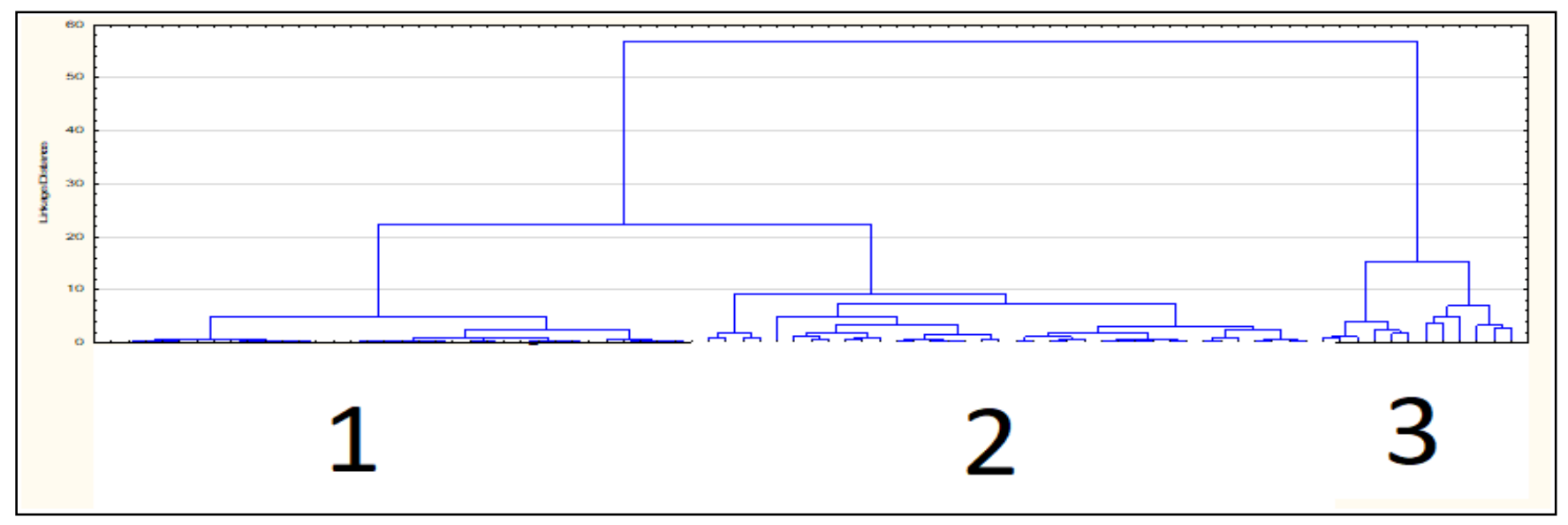

Fig. 8 Clustering of the Russian Federation constituent entities, taking into account the factors determining the volume of production of crop production in the medium term

Source: Suggested by the authors of the article based on the results of the package of applied programs Statistica http://statsoft.ru

The third cluster includes the following regions: Belgorod Region, Voronezh Region, Stavropol Territory, Krasnodar Territory, Rostov Region, Republic of Tatarstan, Volgograd Region, Omsk Region, Republic of Bashkortostan, Orenburg Region, Saratov Region, Altai Territory.

Based on the results of cluster analysis, it can be argued that the constituencies, which are part of the third cluster, specialize in crop production.

As the Gatev coefficients calculation showed, the structure of the gross crop collection in the Russian Federation and the cultivated acreage in 2017 has changed insignificantly in comparison with 1990. These minor changes determined the distribution of the Russian Federation constituent entities, identified on the basis of cluster analysis, according to the level of plant development in 2017. It can be assumed that in 1990 the Russian Federation constituencies were characterized by a similar level of crop production development. Figure 16 shows the cluster analysis of the data array characterizing the effect of various factors on the development of the livestock sub-sector for the subjects of the Russian Federation in 2017. This array contains the following indicators:

a)volume of production of livestock and poultry for slaughter (thousand tons);

b)volume of milk production (thousand tons);

c)volume of egg production (million pieces);

d)feed consumption for livestock and poultry (thousand tons);

e)number of people employed in agriculture (thousand people). 
On the basis of the cluster analysis, four clusters of subjects of the Russian Federation were distinguished, differing in the features of the development of meat cattle breeding (Fig. 9).

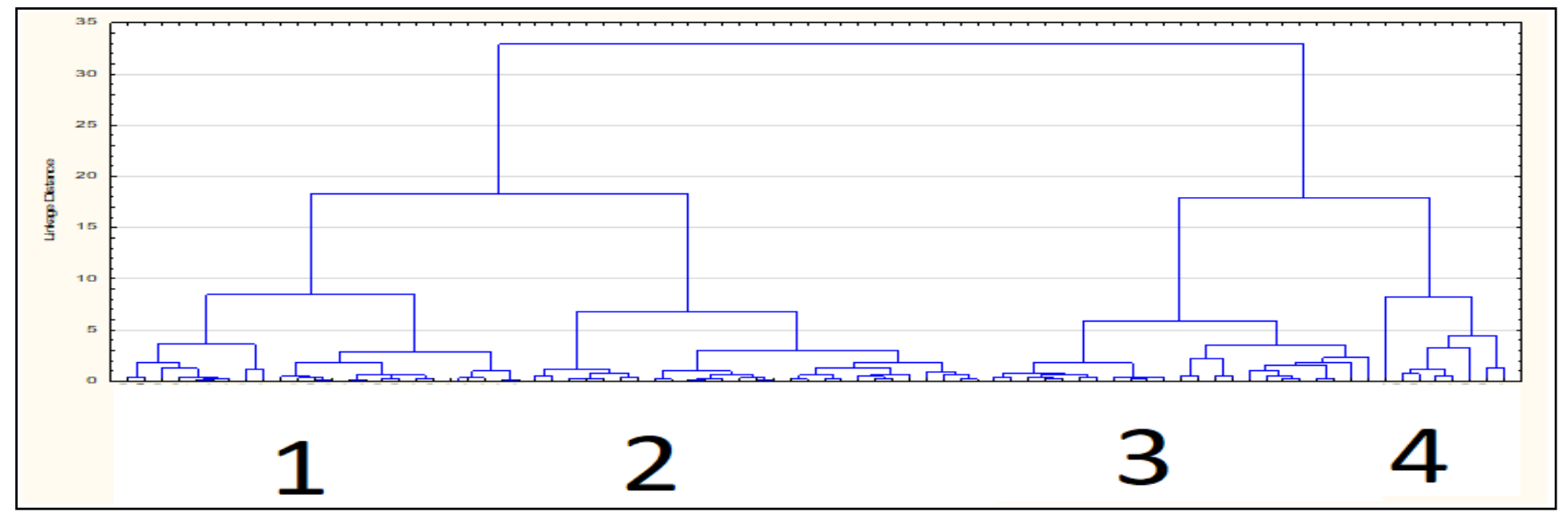

Fig. 9 Clustering of the Russian Federation constituent entities, taking into account the factors determining the volume of production of livestock products in the medium term

Source: Suggested by the authors of the article based on the results of the package of applied programs Statistica http://statsoft.ru

The first cluster includes Moscow, the Sakhalin Region, the Komi Republic, the Khabarovsk Territory, the Murmansk Region, the Magadan Region, the Republic of Karelia, the Kamchatka Territory, the Republic of Adygea, St. Petersburg, the Moscow Region, the Republic of Sakha (Yakutia), and the Kaliningrad Region.

The second cluster includes the Vladimir Region, the Ryazan Region, the Chechen Republic, the Perm Region, the Republic of Buryatia, the Ivanovo Region, the Republic of Tyva, the city of Sevastopol, the Republic of Ingushetia, the Jewish Autonomous Region, the Kostroma Region, the Chukotka Autonomous District.

The third cluster is formed by the Bryansk Region, the Krasnoyarsk Territory, the Novosibirsk Region, the Republic of Crimea, the Saratov Region, the Volgograd Region, the Orenburg Region, the Kursk Region, the Leningrad Region, the Sverdlovsk Region, the Astrakhan Region, the Lipetsk Region, the Kemerovo Region.

The fourth cluster is formed by the Belgorod Region, the Republic of Tatarstan, the Krasnodar Territory, the Rostov Region, the Republic of Bashkortostan, the Stavropol Territory, the Altai Territory, and the Republic of Dagestan.

Regions belonging to the fourth cluster are characterized by the highest indicators of the development of meat cattle breeding. This means that state policy aimed at supporting agricultural producers of the above-mentioned constituent entities of the Russian Federation should help support the potential of these regions. Increasing the level of economic security in this sphere that is carried out through coordination of the risk management process in the industry, the regulator can act as the initiator of cluster projects, choosing the sub-sector and the region to host the cluster. The choice has to be made in accordance with the natural competitive advantages of the region or considerations of food security, in case of need of settling and development of empty or not mastered territories, or increasing the level of transport infrastructure of any region of the country.

At the same time, threats to economic security and the risks of economic agents in the agricultural sector lie in the field of market and operational risks associated with them. Therefore, the main tasks that agro-industrial clusters have to solve are: 


\section{ENTREPRENEURSHIP AND SUSTAINABILITY ISSUES}

ISSN 2345-0282 (online) http://jssidoi.org/jesi/

2019 Volume 7 Number 2 (December)

http://doi.org/10.9770/jesi.2019.7.2(25)

a)creation of infrastructure for primary processing and storage of products. To solve this issue, favorable conditions for attracting investments should be created in this sphere together with expanding opportunities for access of small and medium-sized enterprises that are not capable of creating their own infrastructure;

b)sales of manufactured products. This risk factor is of a systemic nature (especially characteristic for peasant and individual farm holdings of other small businesses, which often do not have alternative sales opportunities, except intermediary organizations (which offer a price that is far from fair, but even allowing operational payback);

c)elimination of the general economic and social decline of agricultural areas. The fulfillment of this task is a consequence of the solution of the two previous. Otherwise, the solution of this task is possible only due to a significant increase in the social burden on budgets of all levels.

\section{Discussion}

The essence of the proposed mechanism for reducing the systematic risks inherent in the activities of economic entities in the field of agriculture, an agro-industrial cluster of a new generation, is as follows. The study suggests the creation of an agro-industrial cluster in the form of a rural municipal formation of a mixed type (MFMT), which is an average population centre, whose inhabitants are usually engaged in agriculture and ensure the functioning of its social infrastructure. At the same time, MFMT is a combination of a system of production, primary processing, storage and marketing of agricultural products and a system of social infrastructure ensuring the quality of life that is comparable to urban. Thus, it is necessary to create an infrastructure that provides social standards to the residents and residents of adjacent territories:

central and local water supply (cold and hot water), including water needed for fire extinguishing; central gas supply or development of liquefied gas supply systems for collective use (Dück, et. al., 2015);

streets with a hard road surface, as well as a network of roads connecting it with populated areas in the service area, establish a passenger transport connection with the regional and regional centers (Kiseleva et. al., 2019);

objects of telephone communication on the basis of stationary and mobile communication systems (Bunich, et. al, 2018);

trade and purchasing objects of consumer cooperation, as well as branches of district housing and communal services enterprises and structures for servicing private household plots (Steinberg, et. al, 2016);

social facilities (pre-school institutions and schools, sports facilities and facilities, environmental tourism

organizations);

necessary assistance (outpatient clinics, emergency rescue depots and posts);

objects of roadside service (catering, car service, gas stations, hotels), etc.

When creating the MFMT, a new type of village is being created, located in significant areas and having all the necessary infrastructure, allowing those who live there to have all the complex of services or entertainment. In fact, MFMT should be a large territorial unit that meets the following criteria:

individual plots of land corresponding to the average farming area in Russia (about 100-150 hectares) or smaller in area, while the resident of the agro-industrial cluster has the possibility of combining several individual plots into a single farm based on the needs of the business;

availability of infrastructure for providing a comfortable life and social environment in the city, including: polyclinics and hospitals, schools and kindergartens, police and fire departments, shops, cafes, restaurants and other entertainment and other infrastructure facilities, i.e. infrastructure, available in modern "sleeping" areas of large cities;

availability of storage infrastructure, primary processing and marketing of agricultural products.

The creation of agro-exchange centers within MFMT would work as a mechanism for the fair price determining. The mechanism of its functioning is as follows - MFMT creates procurement information centers that accumulate 


\section{ENTREPRENEURSHIP AND SUSTAINABILITY ISSUES}

ISSN 2345-0282 (online) http://jssidoi.org/jesi/

2019 Volume 7 Number 2 (December)

http://doi.org/10.9770/jesi.2019.7.2(25)

information about commodity balances and purchase products meeting the requirements of the exchange (Velasquez-Pinas, et. al. 2018). Moreover, the agro-exchange centers_accept bids from traders and deals. The development of the exchange market can subsequently lead to the development of the market of commodity derivatives (the development of the market for derivative financial instruments began precisely with grain futures). Consequently, the creation of MFMT will solve the problem of primary processing, storage and marketing of products, reduce systematic risks of the agricultural sector and will give impetus to the development of the industry, and at the same time, will provide possible partial solution to the problem of megacities' overpopulation.

\section{Conclusion}

To stimulate the agricultural sector development, a distinct advantage is taken by budget subsidies. In particular, the bulk of state support for the agro-industrial complex is provided in the form of subsidies in the framework of various state programs for the agriculture development and the regulation of agricultural markets, raw materials and foodstuffs in the State Program for the Development of Agriculture and Regulation of Agricultural Products, Raw Materials and Foodstuffs for the period up to 2020 (the road map). Based on the systematization of methods for stimulating import substitution in the agro-industrial complex, it was noted that the "road map" focuses on activities in the sphere of ensuring Russia's food security, including the creation of an automated information system, as well as improving land use efficiency, state veterinary and phytosanitary control, customs and tariff regulation of the import of products. At the same time, in the face of a reduction in budgetary resources and shortcomings in price and credit regulators, the use of both tax and non-tax instruments that are versatile and equitable should be expanded. The use of state incentive tools for import substitution must be systematic, that is, subject to a single strategic goal.

In this regard, the main ways to institutionalize import substitution in the agricultural sector should be:

borrowing of advanced technologies, primarily implemented in the EEU countries. A positive aspect of this method is that it allows the production of competitive products of appropriate quality. This is especially true for solving urgent problems in those sectors of the economy where there is a high degree of technological backwardness. However, this method requires significant financial costs and does not have a self-healing device, since it does not develop its own technologies, so it can be used to solve local tasks of the transition period;

creation of a harmonious environment through the selection of institutions capable of becoming incubators for business entities manufacturing products (producing goods, performing work, providing services) within the framework of import substitution, including the creation of conditions under which economic agents could realize the profitability of such activities in the near and medium-term outlook;

stabilization of import substitution by controlling and correcting the institutional movement by involving large corporations, business systems and financial-industrial groups in the import substitution process.

As one of the possible directions for improving the tools of state financial support in the agricultural sector, tax incentives for import substitution could be applied. As for Russia, the current system of tax incentive of agricultural development has the following features:

possibility to apply the zero rate $(0 \%)$ of income tax with in relation to particular activities, as well as reduced rates of value added tax (VAT) at a rate of $10 \%$ for the realization of a number of products (bread, milk, eggs, etc. in accordance with the list set within the Tax Code of the Russian Federation), low rates of the land tax with respect to the agricultural lands and benefits for transport tax for agricultural machinery, delay or installment of the tax payment (up to one year) and investment tax credit (Dudin, et.al, 2015);

possibility to use a special tax regime in the form of a unified agricultural tax (UAT), substituting the payment of tax on the profit of organizations (the profit is taxed at the main rate of 20\%), tax on the property of organizations (except property taxed by cadastral value), the value added tax (excluding VAT, paid on the import of goods on the Russian customs territory). 


\section{ENTREPRENEURSHIP AND SUSTAINABILITY ISSUES}

ISSN 2345-0282 (online) http://jssidoi.org/jesi/

2019 Volume 7 Number 2 (December)

http://doi.org/10.9770/jesi.2019.7.2(25)

It should be noted that despite the fact that the tax system for agricultural producers is positioned by the state as a beneficial tax regime, it did not find a wide use among the taxpayers. The reason is that the Russian Federation Tax Code establishes a closed list of costs, reducing the tax base for UAT. As a result, the costs that have not been put in this list are not taken into account for tax purposes. In turn, in relation to the activity in the general taxation system, the taxpayer has to justify the compliance of costs incurred (the economic validity of costs, documented approval of the costs incurred, and the fact that the purpose of the costs was to gain income or economic benefits). Therefore, agricultural producers have more opportunities to reduce the taxable profit due to the fact that the list of the costs subtracted from the tax base is open (Veselovsky, et. al, 2015). As various economists estimate, the taxpayers, using the general taxation system, are more adapted to business management: the level of the tax burden is comparable to that of special tax regime $(15,88 \%$ vs $13,14 \%$, respectively). Their main activity brings twice more income compared to those organizations using special tax regime (UAT). In addition, the organization applying the general taxation system uses capital assets and equipment more effectively, amount of subsidies achieved is $20 \%$ higher, and the average wages are $10 \%$ higher than in the companies applying UAT (Petrov, et. al, 2019). It should be noted that the existing directions of the tax incentives in the agricultural sector are of scattered character, they are not focused on the import substitution and do not take into account the deep-rooted problems of agriculture. These, in particular, include:

returning the market to national agricultural producers and the rest of the subjects of the agricultural sector;

increasing the attractiveness of the village for the workforce, supporting the standard of living of the rural population;

creating conditions for the production and realization of competitive agricultural products.

In this regard, as part of the institutionalization of import substitution, the tax incentives must be aimed primarily on the solution of the following systematic problems, existing in the following forms:

support of production and providing the consumer with agricultural products, that will allow the country's economy become fully self-sufficient. In order to do that, in the medium term an adequate system of procurement, processing, storage and implementation of these products by the subjects operating in the agricultural sector (including various forms of organizations, e.g. consumer cooperatives) should be formed.

formation of a harmonious business environment by selecting institutions able to become incubators for business entities, producing goods, performing works and providing services within the framework of import substitution, together with the creation of the conditions under which economic agents could understand the benefits of such activities in the nearest and medium-term prospects;

stabilization of import substitution by controlling and correcting the institutional motion, involving large corporations, business systems and financial and industrial groups in the process of import substitution.

These disadvantages of the tax incentive of small business in agricultural sector reveal an objective need to find new ways to develop micro-business taxation. The use of foreign experience in this aspect has been successfully proven in practice, e.g. in France the state actively uses the income tax to implement the main points of protectionist policy (Cooper, et. al., 1994). Moreover, there are three models of taxation in agriculture, depending on the level of farmers' income, the essence of which is to provide tax benefits to small manufacturers with low level of income. In turn, in Australia the main taxes established for farmers are: income tax (30\%) and sales tax (22\%) - the last one is more similar to Russian VAT, as taxpayers can take the incoming tax to offset. The tax on medical care at a rate of 1.5 to $2,5 \%$ is also paid from the taxable profit (Blundell and Robin, 1999). The so-called "primary producers" are entitled to approved benefits of the tax profit organizations - usually it is the transfer of obligations to pay the tax to the future periods. A special system of alignment for income tax for individual farmers in effect - thus a part of the non-taxed profit can be transferred to special funds (Farm Management Deposits) in order to be added to the current assets in unsuccessful years. In the United States farmers are not entitled to the reduced rates on income tax, and the beneficial nature of taxation in agriculture is that most of the farmers have low income and pay income tax at the minimum rate. However, they have a number of other benefits. For example, they are allowed to reduce the taxable base on the payment to the social funds or to pay the 


\section{ENTREPRENEURSHIP AND SUSTAINABILITY ISSUES}

ISSN 2345-0282 (online) http://jssidoi.org/jesi/

2019 Volume 7 Number 2 (December)

http://doi.org/10.9770/jesi.2019.7.2(25)

tax from the average income for the three previous years (Bulyga, 2014), moreover, the farmers can take advantage of accelerated amortization of the fixed assets. These foreign benefits can find successful reflection in the national tax incentive practices in relation to small businesses in the agricultural sector for the countries with a developing market.

Taking into account all mentioned above, it is possible to formulate the following proposals for tax stimulation of the institutionalization of import substitution in the agricultural sector for the countries with a developing market: (1) introduction of target investment benefits of income tax and unified agricultural tax for agricultural organizations purchasing and introducing new technologies in the production, as well as (2) the establishment of the deduction from the tax base the costs on reconstruction, modernization and technical rearmament, plant and equipment with enhances factor. Borrowing environmentally safe technologies should be considered as a priority. Agricultural producers (and first of all, consumer cooperatives engaged in sales and processing of the national agricultural products), should have advantages in comparison with enterprises dealing with processing and marketing products from the imported raw materials. Another perspective direction is the production of ecologically clean products, requested by individuals whose income is above average. Therefore, it seems that specific measures of economic promotion (tax preferences for producing ecologically clean products on the lands newly introduced in the turnover) should be established. The interest in buying ecologically clean agricultural products is a priority to the use of clean technology and resource saving.

\section{References}

Asmi, N. A., Margam, M. 2018. Academic social networking sites for researchers in Central Universities of Delhi: A study of ResearchGate and Academia. Global Knowledge, Memory and Communication, 67(1/2), 91-108. https://doi:10.1108/GKMC-01-2017$\underline{0004}$

Baltgailis, J. 2019. The issues of increasing the effectiveness of teaching comparative economics. Insights into Regional Development, 1(3), 190-199. https://doi.org/10.9770/ird.2019.1.3(1)

Bloshenko, T.A., Ponkratov, V.V., Pozdnyaev, A.S. 2017. Methodology for identifying the differentiated mineral extraction tax rates relating to the recovery of solid minerals, Journal of Environmental Management and Tourism, 8(1), 60-66.

Blundell, R., Robin, J. M. 1999. Estimation in Large and Disaggregated Demand systems: An estimator for conditionally linear systems. Journal of Applied Econometrics, 14, 209-232.

Bodyako, A., Bulyga, R.P., Ponomareva, S.V., Rogulenko, T. 2019. Determination of economically sound criteria to assess the effectiveness of control processes, International Journal of Recent Technology and Engineering, 8(2), 4101-4109.

Bonanno, A., Bimbo, F., Costanigro, M., Lansink, A.O., Viscwcchia, R. 2019. Credence attributes and the quest for a higher price - a hedonic stochastic frontier approach, European Review of Agricultural Economics, 46(2), 163-192.

Bozhkova G.N., Shastina E.M., Kalimullina O.V., Shatunova O.V. 2019. Study of literary images of gifted characters in optional activities as a means to develop capable and talented youth. Space and Culture, India, 7(1), 264-273. https://doi.org/10.20896/saci.v7i1.463

Bulyga, R.P. 2014. Business audit: The new concept of the XXI century, World Applied Sciences Journal, 29(5), 619-622.

Bunich, G.A., Rovenskiy, Y.A., Dashkov, L.P. 2018. Factoring development: Theory and practice, Espacios, 39(19), 9-17.

Cooper, A. C., Gimeno-Gascon, F. J., Woo, C. Y. 1994. Initial Human and Financial Capital as Predictors of New Venture Performance, Journal of Business Venturing, 9(5), 371-395. 


\section{ENTREPRENEURSHIP AND SUSTAINABILITY ISSUES}

ISSN 2345-0282 (online) http://jssidoi.org/jesi/

2019 Volume 7 Number 2 (December)

http://doi.org/10.9770/jesi.2019.7.2(25)

Dück, H., Eufinger, A., Schultes, M. 2015. Company networks in the light of European market power, Business Networks Reloaded, pp. 259-277.

Dudin, M.N., Frolova, E.E., Gryzunova, N.V., Shuvalova, E.B. 2015. The triple helix model as a mechanism for partnership between the state, business, and the scientific-educational community in the area of organizing national innovation development, Asian Social Science, 11(1), 230-238.

Dunets, A., Latysheva, O., Bitter, N., Vakhrushev, I., Shichiyakh, R., \& Zhuruli, G. 2019. The economic and infrastructural basis for the development of tourist space: The essence, structure and typology. Journal of Environmental Management and Tourism, 10(2), 319-327. https://doi:10.14505/jemt.v10.2(34).05

Gatev, K., Galieva, N. 2008. Statistical methods in empirical research and business. Paradigma, p. 428 ISBN 9789543260836

Goloshchapova, L. V., Plaskova, N. S., Prodanova, N. A., Yusupova, S. Y., \& Pozdeeva, S. N. 2018. Analytical review of risks of loss of profits in cargo transportation. International Journal of Mechanical Engineering and Technology, 9(11), 1897-1902.

Goryushkina, N. E., Gaifutdinova, T. V., Logvina, E. V., Redkin, A. G., Kudryavtsev, V. V., \& Shol, Y. N. 2019. Basic principles of tourist services market segmentation. International Journal of Economics and Business Administration, 7(2), 139-150

Goryushkina, N. E., Vakhrushev, I. B., Akhmetova, M. K., Otto, O. V., Pesotskaya, E. V., \& Voinova, N. E. 2018. The world hotel market: Current state and development trends. International Journal of Mechanical Engineering and Technology, 9(12), 618-627.

Guerrero, J.W.G., Toscano, A.D.R., Pacheco, L.V., Tovar, J.O. 2018. Analysis of the energetic and productive effects derived by the installation of a conveyor belt in the metal-mechanic industry, International Journal of Energy Economics and Policy, 8(6), 196-201.

Hayami, Y., Ruttan, V. W. 1970. Agricultural productivity differences among countries, The American Economic Review, 60(5), 895-911.

Hoekman, B., Ng., F., Olarreaga, M. 2004. Agricultural tariffs or subsidies: which are more important for developing economies, The World Bank Economic Review, 18(2), 175-204. https://doi:10.1093/wber/lhh037

Ivanova, Y., Nikeryasova, V., Balikhina, N., Savrukov, A. 2018. Ways to improve the mineral replacement tax system: Taking the experience of commonwealth of independent states countries, International Journal of Energy Economics and Policy, 8(5), 97-103.

Jeffrey, M. G., Maria, B. 2018. Designing agricultural economics and agribusiness undergraduate programs, Journal of Agricultural \& Applied Economics, 50(3), 1-30

Jones, A. 2019. Parallel Oppressions. Journal of Culture and Values in Education, 2(1), 18-33. Retrieved from http://cultureandvalues.org/index.php/JCV/article/view/31

Kevorkova, Z.A., Petrov, A.M., Savina, N.V. 2019. Towards liabilities of corporate systems, International Journal of Civil Engineering and Technology, 10 (2), 1582-1593

Korableva, O. N., Kalimullina, O. V., Zaytseva, A. A., \& Larionov, A. I. 2018. Elaboration of database for the subject domain of innovation and economic growth potential. Paper presented at the Proceedings of the 31st International Business Information Management Association Conference, IBIMA 2018: Innovation Management and Education Excellence through Vision 2020, 6065-6073.

Kiseleva, I.A., Kuznetsov, V.I., Sadovnikova, N.A., Chernysheva, E.N., Androshina, I.S. 2019. Mathematical modeling of investment risks, International Journal of Innovative Technology and Exploring Engineering, 8(7), 2376-2379

Kuznetsova, I. G., Voronkova, O. Y., Nimatulaev, M. M., Ruiga, I. R., Zhuruli, G. N., \& Levichev, V. E. 2019. Ensuring the national security of agriculture in the digital era through the formation of human capital. International Journal of Economics and Business Administration, 7, 558-569. 


\section{ENTREPRENEURSHIP AND SUSTAINABILITY ISSUES}

ISSN 2345-0282 (online) http://jssidoi.org/jesi/

2019 Volume 7 Number 2 (December)

http://doi.org/10.9770/jesi.2019.7.2(25)

Makki, M. F., Suslinawati, Y. F. 2012. Impacts of climate change on productivity and efficiency paddy farms: Empirical evidence on tidal swampland South Kalimantan Province - Indonesia, Journal of Economics and Sustainable Development, 3(14), 66-72

Murray, T., Ginman, P.J. 1976. An Empirical Examination of the Traditional Aggregate Import Demand Model, The Review of Economics and Statistics, 58(1), 75-80.

Palleto, A., Geitner, C., Grilli, G., Hastik, R., Pastorella, F., Rodrigez, G.L. 2015. Mapping the value of ecosystem services: A case study from the Austrian Alps, Annals of Forest Research, 58(1), 157-175.

Petkov, L. 2017. In Memoriam - Prof. Dr. Ec. Scs. Kiril Gatev. Economic Idea, 3, pp. 154-154

Petrov, A.M., Nikiforova, E.V., Kiseleva, N.P., Grishkina, S.N., Lihtarova, O.V. 2019. Creation of the reporting on sustainable development of companies based on socioeconomic measurement statistics, International Journal of Recent Technology and Engineering, 8(2), 4005-4012.

Prodanova, N., Plaskova, N., Popova, L., Maslova, I., Dmitrieva, I., Sitnikova, V., \& Kharakoz, J. 2019. The role of IT tools when introducing integrated reporting in corporate communication. Journal of Advanced Research in Dynamical and Control Systems, 11(8 Special Issue), 411-415.

Plaskova, N. S., Prodanova, N. A., Zatsarinnaya, E. I., Korshunova, L. N., \& Chumakova, N. V. 2017. Methodological support of organizations implementing innovative activities investment attractiveness estimation. Journal of Advanced Research in Law and Economics, 8(8), 2533-2539. https://doi:10.14505/jarle.v8.8(30).25

Pulford, G. 2005. Taxonomy of multiple target tracking methods, Radar, Sonar and Navigation proceeding, 152(5), 265-272

Rupeika-Apoga, R., Zaidi, H.S., Thalassinos, E.Y. \& Thalassinos, I.E. 2018. Bank Stability: The Case of Nordic and Non-Nordic Banks in Latvia. International Journal of Economics \& Business Administration, 6(2), 39-55.

Sharafutdinov, R., Gerasimov, V., Akhmetshin, E., Karasik, E., \& Kalimullina, O. 2018. Inclusive development index in Russia: analysis, methods, possibility of application. National Academy of Managerial Staff of Culture and Arts Herald, 2(2), 1-4.

Shatunova O., Anisimova T., Sabirova F., Kalimullina O. 2019. STEAM as an Innovative Educational Technology. Journal of Social Studies Education Research 10(2), 131-144.

Semeta, A. 2011. EU Commissioner for Taxation and Customs Union, Audit and Anti-Fraud "EU tax policy in support of the EU 2020 Growth Strategy" The FEE Tax Day 2011 Brussels, 11 October 2011 http://europa.eu/press_room/index_ns_en.htm

Singareddy, R. R. R., Ranjan, P., Balamurugan, A., \& Shabana, C. 2019. Financial inclusion remodeling: Including the excluded masses. Space and Culture, India, 6(5), 178-188. https://doi:10.20896/SACI.V6I5.375

Siskova, J. (2015) Application of Multi-Criteria Analysis in the Evaluation of Biogas Plants with Respect to the Stability of the Agricultural System, Acta Universitatis Agriculturae, 2, 12-18

Skryl, T.V. 2017. A paradigm shift in Russia's industrial policy: a raw model to innovative technological growth points, International Journal of Ecological Economics and Statistics, 38(2), 33-48.

Steinberg, M. D., Tkalcec, B., Steinberg, I. M. 2016. Towards a passive contactless sensor for monitoring resistivity in porous materials, Sensors and Actuators, 234, 294-299

Strasberg, P. J., Jayne, T. S., Yamano, T., Nyoro, J., Karanja, D., Strauss, J. 1999. Effects of agricultural commercialization on food crop input use and productivity, International Development Working Papers, 71, 26-32

Sycheva, I. N., Voronkova, O. Y., Kovaleva, I. V., Kuzina, A. F., Bannikov, S. A., \& Titova, S. V. 2019. Motivation in personnel management of a trading enterprise. International Journal of Economics and Business Administration, 7, 570-582. 


\section{ENTREPRENEURSHIP AND SUSTAINABILITY ISSUES}

ISSN 2345-0282 (online) http://jssidoi.org/jesi/

2019 Volume 7 Number 2 (December)

http://doi.org/10.9770/jesi.2019.7.2(25)

Tagliafierro, C., Longo, A., Eetvelde, V., Antrop, M., Hutchinson, W. G. 2013. Landscape economic valuation by integrating landscape ecology into landscape economics, Environmental Science \& Policy, 32, 26 - 36.

Tarman, B. \& Acun, I. 2010. Social Studies Education and a New Social Studies Movement, Journal of Social Studies Education Research. $1(1), 1-16$.

Tarman, B., \& Dev, S. 2018. Editorial: Learning Transformation through Innovation and Sustainability in Educational Practices. Research in Social Sciences and Technology, 3(1), i-ii. Retrieved from http://ressat.org/index.php/ressat/article/view/363

Trofimova, L., Prodanova, N., Korshunova, L., Savina, N., Ulianova, N., Karpova, T., \& Shilova, L. 2019. Public sector entities' reporting and accounting information system. Journal of Advanced Research in Dynamical and Control Systems, 11(8 Special Issue), $416-424$.

Titova, S. V., Surikov, Y. N., Voronkova, O. Y., Skoblikova, T. V., Safonova, I. V., \& Shichiyakh, R. A. 2019. Formation, accumulation and development of human capital in the modern conditions. International Journal of Economics and Business Administration, 7(2), 223230

Velasquez-Pinas, J.A., Pacheco-Torres, P.J., Calle, O.D., Mora-Higuera, L.M., Grimaldo-Guerrero, J.-W., Patricia de-la-Ossa-Ruiz, M. 2018. Production and characterization of biodiesel from cotton oil as an alternative energy in substitution of soybean oil, Journal of Engineering Science and Technology Review, 11 (6), 182-186.

Veselovsky, M.Y., Gnezdova, J.V., Menshikova, M.A., Izmailova, M.A., Romanova, J.A. 2015. Formation of management system for sustainable development of enterprices in the various industries, International Journal of Applied Engineering Research, 10(20), 4117241177.

Voronkova, O. Y., Iakimova, L. A., Frolova, I. I., Shafranskaya, C. I., Kamolov, S. G., \& Prodanova, N. A. 2019. Sustainable development of territories based on the integrated use of industry, resource and environmental potential. International Journal of Economics and Business Administration, 7(2), 151-163.

Ward, J.H. 1963. Hierarchical grouping to optimize an objective function, American Statistical Association, p. 236.

Xiaojiao, J., Andrew, J. C., Thomas, L. 2018. Marsh Economic consequences for tree fruit intermediaries from shocks. Journal of Agricultural and Applied Economics, 49(4), pp. 592-616. https://doi:10.1017/aae.2017.15

Appendix 1. Gatev coefficient calculation for determining structural differences in gross crop collection in the Russian Federation in 2017 as compared to 1990 (by categories of agricultural producers)

\begin{tabular}{|c|c|c|c|c|c|c|c|}
\hline & \multicolumn{2}{|c|}{$\begin{array}{c}\text { Gross harvest of agricultural crops, } \\
\text { thousand tons }\end{array}$} & \multicolumn{2}{|c|}{$d_{i}$} & \multicolumn{2}{|c|}{$d_{\mathrm{f}}^{2}$} & \multirow[t]{2}{*}{$\left(d_{\mathrm{f}}^{2017}-d_{\mathrm{f}}^{1990}\right)^{2}$} \\
\hline & 1990 & 2017 & 1990 & 2017 & 1990 & 2017 & \\
\hline $\begin{array}{l}\text { Agriculture } \\
\text { organizations }\end{array}$ & 953915,51 & 1680794,62 & 0,6527 & 0,6405 & 0,4260 & 0,4103 & 0,0002 \\
\hline Farms & 24035,43 & 591907,32 & 0,0164 & 0,2256 & 0,0003 & 0,0509 & 0,0026 \\
\hline Households & 483514,48 & 351301,77 & 0,3308 & 0,1339 & 0,1095 & 0,0179 & 0,0084 \\
\hline In total: & 1461465,42 & 2624003,71 & 1,0000 & 1,0000 & 0,5358 & 0,4791 & 0,0112 \\
\hline $\begin{array}{l}\text { Gatev } \\
\text { Coefficient }\end{array}$ & & & & & & & 0,11 \\
\hline
\end{tabular}


Appendix 2. Gatev coefficient calculation for determining structural differences in acreage in the Russian Federation in 2017 as compared to 1990 (by federal districts of the Russian Federation)

\begin{tabular}{|c|c|c|c|c|c|c|c|}
\hline & \multicolumn{2}{|c|}{$\begin{array}{c}\text { Sown area, thousand } \\
\text { hectares }\end{array}$} & \multicolumn{2}{|c|}{$d_{i}$} & \multicolumn{2}{|c|}{$d_{i}^{2}$} & \multirow{2}{*}{$\left(d_{\mathrm{d}}^{2017}-d_{f}^{1990}\right)^{2}$} \\
\hline & 1990 & 2017 & 1990 & 2017 & 1990 & 2017 & \\
\hline Central FD & 23744,31 & 15722,22 & 0,2017 & 0,1950 & 0,0407 & 0,0380 & 0,0000 \\
\hline Northwestern FD & 3530,84 & 1433,37 & 0,0300 & 0,0178 & 0,0009 & 0,0003 & 0,0001 \\
\hline Southern FD & 20098,11 & 12719,88 & 0,1707 & 0,1578 & 0,0292 & 0,0249 & 0,0002 \\
\hline North Caucasian FD & 0,00 & 4392,82 & 0,0000 & 0,0545 & 0,0000 & 0,0030 & 0,0030 \\
\hline Volga FD & 35527,36 & 23943,60 & 0,3018 & 0,2970 & 0,0911 & 0,0882 & 0,0000 \\
\hline Ural FD & 8485,21 & 5209,80 & 0,0721 & 0,0646 & 0,0052 & 0,0042 & 0,0001 \\
\hline Siberian FD & 23426,91 & 15119,42 & 0,1990 & 0,1875 & 0,0396 & 0,0352 & 0,0001 \\
\hline Far Eastern FD & 2892,42 & 2076,11 & 0,0246 & 0,0258 & 0,0006 & 0,0007 & 0,0000 \\
\hline In total: & 117705,16 & 80617,22 & 1,0000 & 1,0000 & 0,2073 & 0,1944 & 0,0035 \\
\hline Gatev Coefficient & & & & & & & 0,09 \\
\hline
\end{tabular}

Ravil AKHMADEEV, British Doctor of Philosophy degree (PhD) standard, Associate Professor, Department of Accounting and Taxation, Plekhanov Russian University of Economics, Russian Federation. Research interest: Taxes and taxation, Transfer pricing in taxation, International taxation, Finance and credit, Tax regulation of the economy of agriculture.

ORCID ID: https://orcid.org/0000-0002-7526-0144

Alexander REDKIN, Altai State University, Barnaul, Russian Federation. Candidate of geographical sciences, head of the department recreational geography, tourism and regional marketing. Research interest: spatial organization of the territory, objectives of recreation, regional marketing.

ORCID ID: https://orcid.org/0000-0003-0322-3085 


\section{ENTREPRENEURSHIP AND SUSTAINABILITY ISSUES}

ISSN 2345-0282 (online) http://jssidoi.org/jesi/

2019 Volume 7 Number 2 (December)

http://doi.org/10.9770/jesi.2019.7.2(25)

Nadezda GLUBOKOVA, PhD in Economics, Associate Professor, Department of Accounting and Taxation, Plekhanov Russian University of Economics, Russian Federation. Research interest: Taxes and taxation, Small Business Accounting, Finance, Tax regulation of the economy

ORCID ID: https://orcid.org/0000-0003-3365-1881

Olga BYKANOVA, PhD in Mathematics, Associate Professor, Department of of Higher Mathematics, Plekhanov Russian University of Economics, Russian Federation. Research interest: Mathematical models of economic processes, International taxation, Finance and credit, Tax regulation of the economy.

ORCID ID: https://orcid.org/0000-0003-3915-0180

Liubov MALAKHOVA, MSE, Department of Risk Analysis and Economic Security, Financial University under the Government of the Russian Federation, the Russian Federation, Expert of the Department of Retail business risk management, PJSC "Uralsib Bank", the Russian Federation. Research interest: Taxes and taxation, Statistics, Data Analysis, Data Mining, Mathematical modeling and forecasting.

ORCID ID: https://orcid.org/0000-0002-1583-1443

Anatoly ROGOV, PhD of mathematics, Associate Professor, Department of Quality Management, Russian University of Transport, Russian Federation. Research interest: Finance and credit, Agricultural management, Economy of agriculture.

ORCID ID: https:// orcid.org/0000-0003-4479-0908

Register for an ORCID ID:

https://orcid.org/register

Copyright (C) 2019 by author(s) and VsI Entrepreneurship and Sustainability Center

This work is licensed under the Creative Commons Attribution International License (CC BY).

http://creativecommons.org/licenses/by/4.0/

(c) (i) Open Access 